American Journal of Agricultural and Biological Sciences 3 (2): 476-481, 2008

ISSN 1557-4989

(C) 2008 Science Publications

\title{
Boric Acid Levels in Fresh Noodles and Fish Ball
}

\author{
Pang-Hung Yiu, Jian See, Amartalingam Rajan and Choon-Fah J.Bong \\ Faculty of Agriculture and Food Sciences, Universiti Putra Malaysia Bintulu Campus, \\ Nyabau Road, 97000 Bintulu, Sarawak, Malaysia
}

\begin{abstract}
Boric acid $\left(\mathrm{H}_{3} \mathrm{BO}_{3}\right)$ is detrimental to human health if consumed in excess. However, it continues to be used in the production of food especially noodles and some processed seafood such as fish ball. Five kinds of noodles and a type of fish ball were collected over a period of four weeks from a random sample of manufacturers in Bintulu, Sarawak, Malaysia. The boric acid in these food samples were analyzed by the curcumin-acetic acid method using 2-ethyl-1, 3-hexanediol (EHD) extraction. Results showed that yellow noodles contained highest concentration of boric acid throughout the four weeks with a mean of $2.034 \mu \mathrm{g} \mathrm{g}^{-1}$. In general, the mean concentrations in most food types were inconsistent throughout the sampling period and were relatively low compared to studies reported in Peninsular Malaysia. Although it is not a permitted food preservative or additive, this study showed that local food manufacturers were still using boric acid.
\end{abstract}

Key words: Boric acid, noodles, fish ball, food preservative, food additive

\section{INTRODUCTION}

Boric acid was considered to be relatively benign and non-toxic. Not only was boric acid widely used in the medical profession in the form of ointments and irrigating solutions, the compound was also a common item in household medicine cabinets and nurseries. However, boric acid and borates are now known to be toxic to all cells. It is deleterious to health and its use is not recommended. Potential lethal doses are usually cited as 3-6 g total for infants and 15-20 g total for adults ${ }^{[1]}$. Boric acid has been declared unsafe by an FAO/WHO Expert Committee especially as a food preservative in view of its cumulative nature and its possible use to mask incipient putrefaction ${ }^{[2,3]}$. In the United Kingdom, boric acid was prohibited as a preservative in $1925^{[3]}$. In 1974, Thailand officially banned borax as a food additive ${ }^{[4]}$. Many other countries, including Malaysia, have also prohibited the use of boric acid and borax for preservation of food.

However, boric acid is still being used as food preservative in the country. These chemicals are being added to some food products to control starch gelatinization, enhance colour, texture and flavor. The $\mathrm{Star}^{[5]}$ reported that boric acid is popularly used by food producers and fishmongers to hide the staleness and preserve the freshness of fish, prawn and meat. An outbreak of food poisoning resulting in 13 deaths in children occurred during the Chinese Festival of the
Nine-Emperor Gods in $1988^{[6]}$. The offending food was a Chinese rice noodle called Loh See Fun (LSF). The source was traced to a factory where a banned food preservative was added to make the LSF. The food poisoning was attributed to aflatoxins and boric acid. In a statement released by the Malaysian Health Ministry in early March 2006, there was a high percentage of boric acid misuse as a food preservative in peninsular Malaysia $^{[7]}$. Meanwhile, on June 15, 2007, Consumers Association if Penang (CAP) reported that rice dumplings on sale contained boric acid ranging from 0.4 to $479.6 \mathrm{ppm}^{[8]}$. Samples were collected from Penang, Kuala Lumpur, Ipoh, Taiping and Klang. According to this report, similar cases have also been brought up in 2001 and 2003. In view of the widespread misuse of boric acid in the country, studies to monitor boric acid levels in locally manufactured food are needed.

\section{MATERIALS AND METHODS}

All reagents were analytical grade chemicals and all solutions were stored in chemical resistant polypropylene vessels. Five types of locally manufactured noodles: yellow noodles, wantan noodles (Cantonese egg noodles), koay teow (flat rice noodles), loh see fun (rice noodles), lai fun and fish ball were selected for the study. Samples were collected over a period of four weeks from local manufacturers in

Corresponding Author: Yiu Pang-Hung, Faculty of Agriculture and Food Sciences, Universiti Putra Malaysia (Bintulu Campus), Nyabau Road, 97000 Bintulu, Sarawak, Malaysia Tel: 6086-855432, Fax: 6086-855428 
Am. J. Agril. \& Biol. Sci., 3 (2): 476-481, 2008

Bintulu, Sarawak beginning November 23, 2006. All food samples were homogenized before they were dried in an oven at $80^{\circ} \mathrm{C}$ overnight.

Sample analysis: Boric acid levels were analyzed using curcumin-acetic acid method according to Yamada and Hattori ${ }^{[9]}$ with minor modification. Five grams of dried samples were ashed in muffle furnace at $550^{\circ} \mathrm{C}$ for 16 $\mathrm{h}$. The ashed samples were weighed and dissolved in 2 $\mathrm{mL}$ of $6 \mathrm{M}$ hydrochloric acid. The solution was filtered and diluted to $25 \mathrm{~mL}$ with distilled water and extracted with $4 \mathrm{~mL}$ of 2-ethyl-1, 3-hexanediol (EHD) and chloroform $(1: 4 \mathrm{v} / \mathrm{v})$ mixture for 3 minutes with continueous shaking using vortex mixer. After complete separation, $1 \mathrm{~mL}$ of the organic phase was transferred into a centrifuge tube 50 and $1 \mathrm{~mL}$ of curcumin-acetic acid solution was added to the solution followed by $0.25 \mathrm{~mL}$ of concentrated sulphuric acid $\left(\mathrm{H}_{2} \mathrm{SO}_{4}\right)$. The mixture was allowed to stand for 30 minutes and topped up to $50 \mathrm{~mL}$ with $99.5 \%$ ethyl alcohol. The absorbance was read at $550 \mathrm{~nm}$ wavelength using UV-visible spectrophotometer (Cary, WinUV). Total boric acid present in test solutions were calculated from standard curve derived using standard boric acid solutions $(0,1,5,10,15,20,25$ and $30 \mathrm{ppm})$.

Boric acid recovery study: This procedure was carried out to ensure the reliability of curcumin colorimetry method for boric acid determination in food samples. A $1 \mathrm{~mL}$ sample of each boric acid standard $(0,5,20,30$ and $50 \mathrm{ppm}$ ) was added to five grams of dried yellow noodles. All samples were treated and analyzed as described above.

Experimental design and statistical analysis: The experimental design used was a completely randomized design (CRD). The data were analyzed using Analysis of Variance (ANOVA) procedure and treatment means were statistically compared by Duncan New Multiple Range Test (DNMRT) at the 5\% level of significance. The statistical software used was the Statistical Analysis System, version 9.1.

\section{RESULTS AND DISCUSSION}

Recovery study: In this study, total boric acid in food samples was consistent and reliable with a mean recovery of more than $97 \%$ (Table 1), although results of curcumin colorimetry method could be influenced by several factors. A small amount of water contaminating the organic phase can affect the colour development of the boron-curcumin complex ${ }^{[9]}$. Besides that, the dry ashing of samples could be prone to contamination
Table 1: Boric acid recovery study

\begin{tabular}{llll}
\hline Treatment & $\mathrm{H}_{3} \mathrm{BO}_{3}(\mu \mathrm{g})$ & & \\
& - Added & Recovered & \% recovery \\
\hline $\mathrm{Y}$ & 0 & 0.4 & - \\
$\mathrm{T} 5$ & 5 & 5.3 & 98.6 \\
T20 & 20 & 19.9 & 97.6 \\
T30 & 30 & 29.5 & 97.2 \\
T50 & 50 & 49.7 & 98.6 \\
\hline
\end{tabular}

Note: Mean of five food samples with $5 \mathrm{~g}$ each



Fig. 1: Concentration of boric acid in yellow noodles from different manufacturers over four weeks. (Means with same alphabets within each manufacturer are not significantly different at $\mathrm{p}=0.05$, DNMRT).

from oven walls and evaporative losses of trace elements ${ }^{[10]}$. The results of the present study are also in agreement with the findings of Mizura et al. ${ }^{[11]}$ that curcumin colorimetry is the method of choice for boric acid determination.

Boric acid content in yellow noodles: The mean concentration of boric acid for manufacturer Y1 from week one to week four was 3.58, 1.91, 1.86 and $1.44 \mu \mathrm{g} \mathrm{g}^{-1}$, respectively (Fig. 1).

The concentration of boric acid in samples from Manufacturer Y2 decreased from week one to week two from 4.33 to $1.71 \mu \mathrm{g} \mathrm{g}^{-1}$. Based on the four weeks data, Manufacturer Y2 recorded the highest level of boric acid content in week one $\left(4.33 \mu \mathrm{g} \mathrm{g}^{-1}\right)$ and there were no significant differences in concentration of boric acid between week two, three and four. Manufacturer Y3 showed high values for boric acid levels in week one with $\left(3.46 \mu \mathrm{g} \mathrm{g}^{-1}\right)$ and week four $\left(3.37 \mu \mathrm{g} \mathrm{g}^{-1}\right)$, while the levels were lower for week two and three with values of 1.84 and $1.78 \mu \mathrm{g} \mathrm{g}^{-1}$, respectively.

The boric acid content in samples taken from Manufacturer Y4 from week one to week four were 
3.68, $1.49,1.90$ and $1.84 \mu \mathrm{g} \mathrm{g}{ }^{-1}$, respectively. The samples collected from Manufacturer Y5 showed no significant differences throughout the four weeks, with $2.90,2.12,2.00$ and $2.58 \mu \mathrm{g} \mathrm{g}^{-1}$, respectively.

The concentrations of boric acid in samples from Manufacturer Y6 were similar to Manufacturer Y5. The concentrations of boric acid in samples collected from Manufacturer Y6 over the four weeks were 2.27, 1.46, 0.79 and $1.28 \mu \mathrm{g} \mathrm{g}^{-1}$, respectively. Yellow noodles from manufacturer Y7 contained the lowest amount of boric acid in week one $\left(0.62 \mu \mathrm{g} \mathrm{g}^{-1}\right)$ compared to week two $\left(1.30 \mu \mathrm{g} \mathrm{g}^{-1}\right)$ and four $\left(1.33 \mu \mathrm{g} \mathrm{g}^{-1}\right)$.

The results showed that the amount of boric acid in the noodles varied over time and amongst manufacturers (Fig.1). Amounts of boric acid added by some individual manufacturers fluctuated with time and were inconsistent (Y2, Y3 and Y7). This was expected as there was no consistency in measurement of boric acid being added to the noodles by these small-scale producers. At different production periods, different workers could be handling the addition of boric acid. In most cases of small scale manufacturers, the addition of preservatives to food products is based on approximation rather than exact measurement. Besides that, non-uniform or poor mixing of boric acid with the flour and other ingredients during the production process can also cause variation in concentration.

Boric acid content in fish ball: Fish ball samples were collected from 4 local manufacturers i.e. F1, F2, F3 and F4 over four weeks. The boric acid content in fish ball samples from Manufacturer F1 and F4 was inconsistent over the sampling period as shown in Fig. 2. In samples from F1 the boric acid concentration in week two (1.57 $\left.\mu \mathrm{g} \mathrm{g}^{-1}\right)$ and three $\left(1.08 \mu \mathrm{g} \mathrm{g}^{-1}\right)$ were higher compared to week one $\left(1.07 \mu \mathrm{g} \mathrm{g}^{-1}\right)$ and week four $\left(1.58 \mu \mathrm{g} \mathrm{g}^{-1}\right)$. Manufacturer F2 was consistent from week one to week four with concentrations ranging from 0.97 to $1.21 \mu \mathrm{g} \mathrm{g}^{-1}$, respectively. As for Manufacturer F3, again the values were consistent throughout the four weeks with concentrations ranging from 0.86 to $1.38 \mu \mathrm{g} \mathrm{g}^{-1}$. Manufacturer F4 was almost the same in week one and week two, with values of 1.30 and $1.29 \mu \mathrm{g} \mathrm{g} \mathrm{g}^{-1}$, respectively. On the following week, the concentration was $0.86 \mu \mathrm{g} \mathrm{g}^{-1}$ and increased to $1.57 \mu \mathrm{g} \mathrm{g}^{-1}$ in the fourth week.

Boric acid content in 'wantan' noodle: The concentrations of boric acid in wantan noodle from five manufacturers (W1, W2, W3, W4 and W5) over the period of four weeks are shown in Fig. 3. There was no significant difference in boric acid concentration in the samples of wantan noodle taken from Manufacturer W1

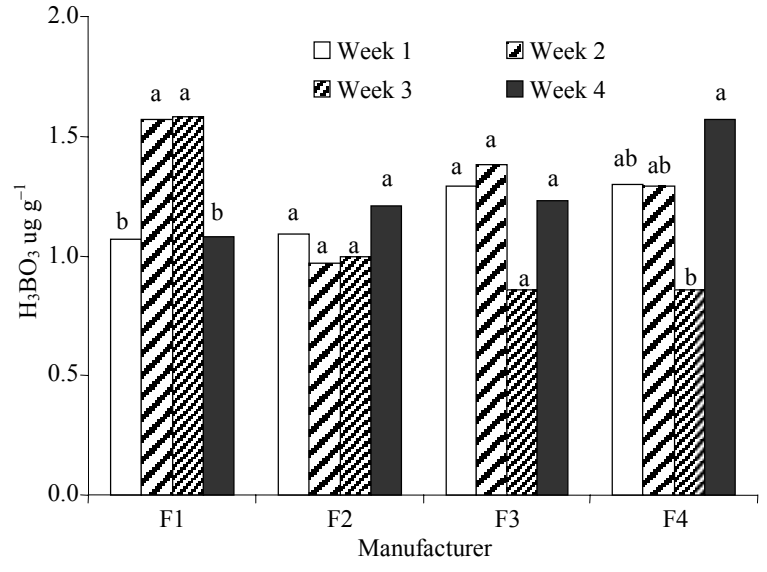

Fig. 2: Concentration of boric acid in fish ball from different manufacturers over four weeks. (Means with same alphabets within each manufacturer are not significantly different at $\mathrm{p}=0.05 ;$ DNMRT)

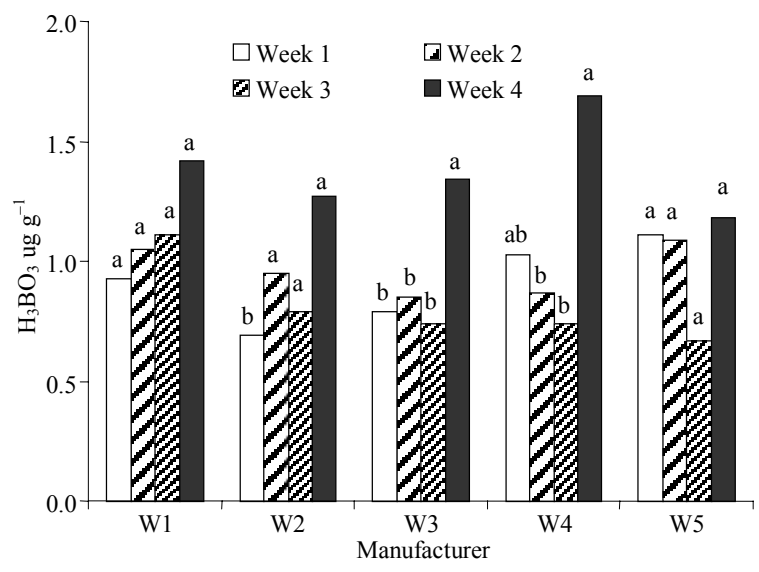

Fig. 3: Concentration of boric acid in wantan noodle from different manufacturers over four weeks. (Means with same alphabets within each manufacturer are not significantly different at $\mathrm{p}=0.05$; DNMRT).

over the four weeks, with levels ranging from 0.93 to $1.42 \mu \mathrm{g} \mathrm{g}^{-1}$. In samples from Manufacturer W2, there was fluctuation from week one to week four with a range of between 0.69 to $1.27 \mu \mathrm{g} \mathrm{g}^{-1}$. For Manufacturer W3, the concentrations of boric acid were uniform in the first three weeks, which were $0.79,0.85$ and $0.74 \mu \mathrm{g} \mathrm{g}^{-1}$, respectively. In the fourth week, the boric acid level was significantly highest $\left(1.34 \mu \mathrm{g} \mathrm{g}^{-1}\right)$. Samples from manufacturer W4 recorded $1.03 \mu \mathrm{g} \mathrm{g}^{-1}$ (week one), $0.87 \mu \mathrm{g} \mathrm{g}^{-1}$ (week two) and $0.74 \mu \mathrm{g} \mathrm{g}^{-1}$ (week three). The concentration in the fourth week 


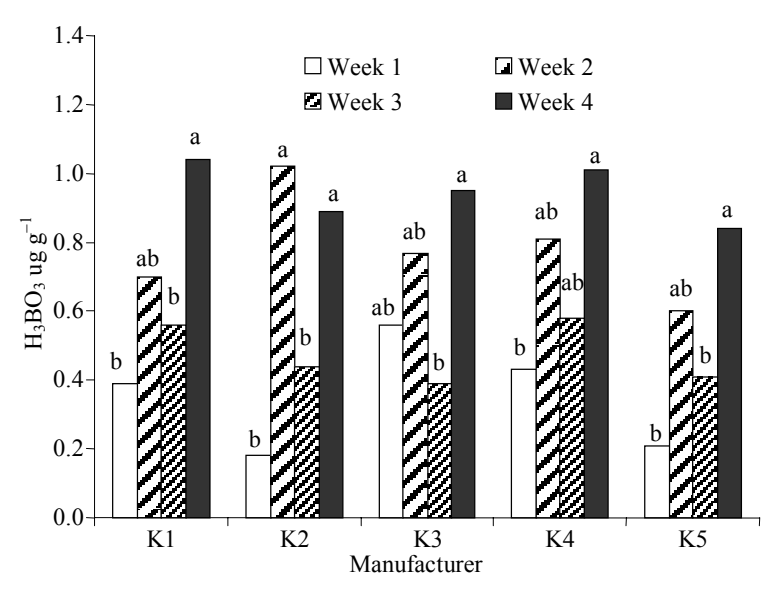

Fig. 4: Concentration of boric acid in koay teow from different manufacturers over four weeks. (Means with same alphabets within each manufacturer are not significantly different at $\mathrm{p}=0.05 ;$ DNMRT)

(1.69 $\left.\mu \mathrm{g} \mathrm{g}^{-1}\right)$ was more than twice the concentration of week two or three. The levels of boric acid in samples produced by Manufacturer W5 were relatively consistent ranging from 0.67 to $1.18 \mu \mathrm{g} \mathrm{g}^{-1}$.

Boric acid content in 'koay teow' noodle: The concentrations of boric acid in koay teow noodles produced by five manufacturers $(\mathrm{K} 1, \mathrm{~K} 2, \mathrm{~K} 3, \mathrm{~K} 4$ and K5) over a period of four weeks are presented in Fig. 4. An overview from the graph shows that the concentrations in all cases fluctuated throughout the four weeks. For Manufacture K1, the content of boric acid in week one to week four were $0.39,0.70,0.56$ and $1.04 \mu \mathrm{g} \mathrm{g}^{-1}$, respectively. In samples from Manufacture $\mathrm{K} 2$, the boric acid contents were inconsistent throughout the four weeks and ranged between 0.44 to $1.02 \mu \mathrm{g} \mathrm{g}^{-1}$. The concentrations for Manufacturer K3 over the four weeks were 0.56, 0.77, 0.39 and $0.95 \mu \mathrm{g} \mathrm{g}^{-1}$, respectively. For Manufacturer K4 and Manufacturer K5, the concentrations obtained were also not consistent. In samples from Manufacturer K4, the concentrations ranged from a low value of 0.43 to $1.01 \mu \mathrm{g} \mathrm{g}^{-1}$, while values for Manufacturer K5 ranged between 0.21 and $0.84 \mu \mathrm{g} \mathrm{g}^{-1}$.

\section{Boric acid content in all food types}

Mean concentrations from one to four weeks: The mean concentration of boric acid in yellow noodle was significantly higher in week one with a mean value of $2.98 \mu \mathrm{g} \mathrm{g}^{-1}$ compared to other weeks (Table 2). There were no significant differences in mean concentration

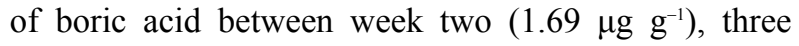

(1.57 $\left.\mu \mathrm{g} \mathrm{g}^{-1}\right)$ and four week $\left(1.90 \mu \mathrm{g} \mathrm{g}^{-1}\right)$. The mean concentrations of boric acid for fish ball were consistent over the four weeks, with values of $1.08,1.19,1.27$ and $1.30 \mu \mathrm{g} \mathrm{g}^{-1}$, respectively. This suggests that the fish ball manufacturers practiced reasonable control over the amount of boric acid added into the fish balls.

In 'wantan' noodles, the concentration of boric acid in week one $\left(0.91 \mu \mathrm{g} \mathrm{g}^{-1}\right)$ showed no significant differences from week two $\left(0.96 \mu \mathrm{g} \mathrm{g}^{-1}\right)$ and three $\left(0.81 \mu \mathrm{g} \mathrm{g}^{-1}\right)$. The concentration of boric acid in 'wantan' noodle was consistent over the first three weeks. However, in the fourth week, the mean value of boric acid was significantly higher than the first three weeks, with a value of $1.38 \mu \mathrm{g} \mathrm{g}^{-1}$. This non-uniformity in concentration over time is attributed to poor control in boric acid usage.

In 'koay teow' noodles, the mean concentration of boric acid in week one $\left(0.35 \mu \mathrm{g} \mathrm{g}^{-1}\right)$ and week three $\left(0.48 \mu \mathrm{g} \mathrm{g}^{-1}\right)$ showed no significant differences (Table $2)$. In the second week $\left(0.78 \mu \mathrm{g} \mathrm{g}^{-1}\right)$ and in week four $\left(0.95 \mu \mathrm{g} \mathrm{g}^{-1}\right)$, the concentrations were significantly higher than the other two weeks. With a mean concentration of $0.638 \mu \mathrm{g} \mathrm{g}^{-1}$, the level of boric acid in 'koay teow' was relatively lower than yellow noodles and fish balls. In general, the mean concentrations of boric acid were inconsistent from week one to week four (Table 2), while, the boric acid content in samples from each manufacturer fluctuated over time (Figs. 14). As most noodles manufactured in Bintulu were made by small-scale manufacturers or produced at home, the wide variation can be attributed to lack of quality control and inconsistent measurement of boric acid added into the noodles. In addition, the nonuniform mixing of boric acid can also cause different concentration levels in different strands of noodle in a single packet.

The concentrations of boric acid content in 'loh see fun' noodles recorded fluctuated over the four weeks (Table 2). The content of boric acid showed no significant differences from week one to week three, with values of $0.35,0.67$ and $0.42 \mu \mathrm{g} \mathrm{g}^{-1}$, respectively. However, there was a significant increase in the level of boric acid in the 'loh see fun' sample in week four $\left(1.08 \mu \mathrm{g} \mathrm{g}^{-1}\right)$.

The concentration of boric acid in 'lai fun' noodles also showed some fluctuation over the four weeks (Table 2). The concentration was $0.07 \mu \mathrm{g} \mathrm{g}^{-1}$ in week one and $0.80 \mu \mathrm{g} \mathrm{g}^{-1}$ in the second week. In the third week, the concentration of boric acid was $0.44 \mu \mathrm{g} \mathrm{g}^{-1}$, but increased significantly in the following week to $1.00 \mu \mathrm{g} \mathrm{g}^{-1}$. The concentration of boric acid in week one was not significantly different from the third week, while the concentration of boric acid recorded in the 
Am. J. Agril. \& Biol. Sci., 3 (2): 476-481, 2008

Table 2: Mean boric acid concentration in the food samples

\begin{tabular}{|c|c|c|c|c|c|c|}
\hline \multirow[b]{3}{*}{ Type of Food } & \multirow[b]{3}{*}{ Manufacturer } & \multicolumn{5}{|c|}{ Means Boric acid concentration $\left(\mu \mathrm{g} \mathrm{g}^{-1}\right)$} \\
\hline & & \multicolumn{4}{|l|}{ Week $^{1}$} & \multirow{2}{*}{$\begin{array}{l}\text { Over four } \\
\text { consecutive weeks }\end{array}$} \\
\hline & & 1 & 2 & 3 & 4 & \\
\hline Yellow noodle & 7 & $2.98 \mathrm{a}$ & $1.69 \mathrm{~b}$ & $1.57 \mathrm{~b}$ & $1.90 \mathrm{~b}$ & $2.034 \mathrm{a}$ \\
\hline Fish ball & 4 & $1.19 \mathrm{a}$ & $1.30 \mathrm{a}$ & $1.08 \mathrm{a}$ & $1.27 \mathrm{a}$ & $1.209 \mathrm{~b}$ \\
\hline Wantan noodle & 5 & $0.91 \mathrm{~b}$ & $0.96 \mathrm{~b}$ & $0.81 \mathrm{~b}$ & $1.38 \mathrm{a}$ & $1.015 \mathrm{bc}$ \\
\hline Koay teow noodle & 5 & $0.35 \mathrm{c}$ & $0.78 \mathrm{~b}$ & $0.48 \mathrm{c}$ & $0.95 \mathrm{a}$ & $0.638 \mathrm{c}$ \\
\hline Loh See Fun noodle & 1 & $0.35 \mathrm{~b}$ & $0.67 \mathrm{ab}$ & $0.42 \mathrm{~b}$ & $1.08 \mathrm{a}$ & $0.629 \mathrm{c}$ \\
\hline Lai fun' noodle & 1 & $0.07 \mathrm{c}$ & $0.80 \mathrm{ab}$ & $0.44 \mathrm{bc}$ & $1.00 \mathrm{a}$ & $0.577 \mathrm{c}$ \\
\hline
\end{tabular}

${ }^{1}$ Means within the rows with same alphabets are not significantly different at $p=0.05$; DNMRT)

${ }^{2}$ Means within the columns with same alphabets are not significantly different at $\mathrm{p}=0.05$; DNMRT)

second week was also not significantly different from the third and fourth weeks. This inconsistency could again be related to lack of quality control during processing.

Overall mean concentration over the four consecutive weeks: The overall mean concentration of boric acid averaged over four consecutive weeks was highest in yellow noodles (Table 2). Boric acid content in fish ball was not significantly different from 'wantan' noodle, while 'wantan' noodle was not significantly different from 'koay teow' noodle, 'loh see fun' noodle or 'lai fun' noodle.

The results showed that the concentrations obtained in this study were relatively low compared to concentrations reported in Peninsular Malaysia. The mean concentrations of boric acid reported in selected foods from Peninsular Malaysia were $918 \mu \mathrm{g} \mathrm{g}^{-1}$ in agar-agar strips, $819 \mu \mathrm{g} \mathrm{g}^{-1}$ in mango (pickled), $532 \mu \mathrm{g} \mathrm{g}^{-1}$ in noodles (wet) and $347 \mu \mathrm{g} \mathrm{g}^{-1}$ in fresh prawns ${ }^{[11]}$.

Boric acid was not stated in the list of permitted food preservatives and additives in Malaysia ${ }^{[12]}$. Adding boric acid to food products as preservatives is clearly an illegal act committed by the local manufacturers. Among all the five types of noodles and the fish ball, the concentration of boric acid was highest in yellow noodle throughout all the four weeks of sampling. This was followed by fish ball, 'wantan' noodle, 'koay teow' noodle, 'lai fun' noodle and 'loh see fun' noodle. Higher quantity of boric acid added to yellow noodles was probably to extent the shelf life of this product with a higher market demand compared to the rest of the food samples.

\section{CONCLUSION}

From the study, boric acid was found in all the food types tested and the concentrations varied among foods. The concentration of boric acid was highest in yellow noodles, followed by fish ball, 'wantan' noodles, 'koay teow' noodles, 'lai fun' noodles and least in 'loh see fun' noodles. The mean concentration of boric acid in all food tested fluctuated throughout the four weeks, except fish ball. The probable cause to this inconsistency could be due to absence of standard measurement practices or lack of proper supervision of workers by these small-scale manufacturers. However, the levels of boric acid recorded in this study were relatively lower compared to a similar study conducted in Peninsular Malaysia. This study further confirms that local food manufacturers were still using boric acid although it is not a permitted food preservative in Malaysia.

\section{ACKNOWLEDGEMENT}

This study was supported by the Faculty of Agriculture and Food Sciences, Universiti Putra Malaysia Bintulu Campus. We are grateful to all faculty members for their cooperation and forbearance.

\section{REFERENCES}

1. Litovitz, T.L., W. Klein-Schwartz, G.M. Oderda and B.F. Schmitz, 1988. Clinical manifestations of toxicity in a series of 784 boric acid ingestions. Am. J. Emerg. Med., 6: 209-213.

2. Davidson, S., R. Passmore, J.F. Brock and A.S. Truswell, 1975. Human nutrition and dietetics. $6^{\text {th }}$ Ed. Great Britain: Churchill Livingstone.

3. Egan, H., R.S. Kirk and S. Sawyer, 1981. Pearsons chemical analysis of foods. $8^{\text {th }}$ Ed. London: Churchill Livingstone.

4. Monsereenusorn, Y., 1982. Common food additives and spices in Thailand-toxicological effects. In Adverse effects of foods. Jelliffe, E.F.P. and D.B. Jelliffe, (Eds.). New York: Plenum, pp: 195-201. 
5. The Star, 2000. Stop the use of boric acid as food preservative. August 25, 2000, pp:15.

6. Chao, T.C., S.M. Maxwell and S.Y. Wong, 1991. An outbreak of alfatoxicosis and boric acid poisoning in Malaysia: A clinicopathological study. J. Pathol., 164: 225.

7. The Star, 2006. Yellow noodles contain highest level of boric acid. March 1, 2006, pp: 14.

8. The Star, 2007. Make your own bak chang. June 16, 2007, pp: 12.

9. Yamada, H. and T. Hattori, 1986. Determination of total boron in soil by the curcumin-acetic acid method after extraction with 2-ethyl-1,3hexanediol, Soil Sci. Plant Nutr., 32: 135-139.
10. Mair, J.W.Jr. and H.G. Day, 1972. Curcumin method for spectrophotometric determination of boron extracted from radiofrequency ashed animal tissues using 2-ethyl-1,3-hexanediol. Anal. Chem., 44: 2015-2017.

11. Mizura, S.S., E.S. Tee and H.E. Ooi, 1990. Determination of boric acid in foods: Comparative study of three methods. J. Sci. Food Agric., 55: 261-268.

12. Ministry of Health Malaysia, 1985. Food Regulations 1985 (PU(A) 437/85). Government Printer, Kuala Lumpur. 